\title{
FAKTOR-FAKTOR YANG MEMPENGARUHI PERMINTAAN INDUSTRI HILIR DOMESTIK TERHADAP BIJI KAKAO
}

\author{
Faris Maulana Satria ${ }^{1}$, Adi Nugraha ${ }^{2}$, Eka Purna Yudha ${ }^{2}$ dan Ernah $^{2}$ \\ ${ }^{1}$ Program Studi Agribisnis, Universitas Padjadjaran \\ ${ }^{2}$ Departemen Sosial Ekonomi, Fakultas Pertanian, Universitas Padjadjaran
}

\begin{abstract}
ABSTRAK
Kakao merupakan salah satu komoditas yang memiliki kontribusi terbesar terhadap perekonomian Indonesia. Kakao memiliki potensi hilirisasasi yang sangat baik, dimana produk hilir kakao sangat beragam dan memiliki nilai ekonomis yang tinggi. Pemerintah menetapkan bubuk kakao dan lemak kakao sebagai produk hilir utama yang dihasilkan Indonesia. Perkembangan dapat dilihat pada perubahan jenis produk kakao yang diekspor. Ekspor biji kakao terus mengalami penurunan, sementara ekspor bubuk kakao dan lemak kakao terus mengalami peningkatan. Perkembangan pada industri juga dapat dilihat pada peningkatan impor biji kakao oleh Indonesia yang mengindikasikan peningkatan pada konsumsi biji kakao oleh industri hilir domestik. Penelitian ini dilakukan dengan tujuan menganalisis trend perubahan produksi biji kakao, konsumsi biji kakao oleh industri, dan produksi produk hilir dengan menggunakan analisis trend dan grafik, serta mengidentifikasi faktor-faktor yang mempengaruhi permintaan industri hilir domestik terhadap biji kakao menggunakan analisis regresi linier berganda metode Ordinary Least Square (OLS) dengan bantuan software SPSS versi 25. Hasil penelitian menunjukkan bahwa produksi dan volume ekspor biji kakao mengalami penurunan, sementara produksi produk hilir dan konsumsi biji kakao oleh industri meningkat. Faktor-faktor yang mempengaruhi permintaan industri hilir terhadap biji kakao secara signifikan adalah harga biji kakao, harga lemak kakao, harga bubuk kakao, dan produksi bubuk kakao.
\end{abstract}

Kata Kunci: Bubuk Kakao, Lemak Kakao, Trend Perubahan, Permintaan Industri, Ordinary Least Square

\begin{abstract}
Cocoa has one of the highest contribution towards Indonesian economy among other agricultural commodities. Cocoa has huge potential in the downstream sector, reflected by the many variations of cocoa-based products with high economic value. Government of Indonesia declared cocoa powder and cocoa butter as the main product of downstream cocoa industry. Development of the cocoa industry downstream sector is indicated in the shift of cocoa based-products exported to various countries around the world, from raw cocoa seeds to cocoa powder and cocoa butter. Increase in Indonesian import of cocoa beans shows that there is an increase in the industry's consumption of raw cocoa beans. The purpose of this research is to analyze the trend and dynamics of Indonesia's cocoa bean production, cocoa bean export, downstream sector's production, and downstream sector's cocoa bean consumption, and to identify factors that affect downstream cocoa industry's demand of cocoa beans using Ordinary Least Squares regression analysis. The result of this research shows that Indonesia's cocoa bean export and production is trending downward, while downstream production and consumption shows a positive developing trend. Factors that affect the cocoa downstream industry's demand are prices of cocoa bean, cocoa butter, cocoa powder, and the amount of cocoa powder produced by the industry.
\end{abstract}

Keywords: Cocoa Powder, Cocoa Butter, Trend, Dowsntream Industry's Demand, Ordinary Least Square 


\section{Pendahuluan}

Perkebunan merupakan subsektor pertanian dengan kontribusi terbesar terahadap PDB Indonesia. Pada tahun 2018, Indonesia merupakan produsen kakao terbesar ketiga dunia setelah Pantai Gading dan Ghana. Industri kakao diharapkan dapat terus berkembang sehingga kontribusi terhadap perekonomian Indonesia dapat terus meningkat.

Produksi kakao Indonesia dari tahun 2010 hingga 2018 terus mengalami penurunan yang disebabkan oleh buruknya rehabilitasi pada tanaman-tanaman yang sudah tidak produktif berumur diatas 25 tahun. Selain itu, luas lahan perkebunan kakao pada periode yang sama juga mengalami penurunan. Meskipun demikian, kakao dan produk olahannya yang memiliki potensi tinggi dalam segi nilai ekonomi tetap menjadi salah satu fokus utama pemerintahan dalam perkembangan industri. Hal ini terbukti dalam keputusan pemerintah menyertakan industri kakao sebagai industri yang perkembangannya diprioritaskan sebagaimana tertera pada Rencana Induk Pengembangan Industri Nasional (RIPIN) Tahun 2015-2035. Produk hilir kakao yang diutamakan adalah bubuk kakao, lemak kakao, minuman, makanan suplemen kesehatan, dan berbagai bahan pangan fungsional lainnya. Produksi produk olahan kakao pun mengalami peningkatan dimana pada tahun 2017, Indonesia memperoduksi 137.469 ton lemak kakao dan 27.389 ton bubuk kakao, diikuti dengan produksi produk jadi sekitar delapan ribu ton.

Kebijakan pemerintah mengenai industri kakao pada sektor hulu adalah Gerakan Nasional Peningkatan Produktivitas dan Mutu Kakao yang disebut dengan Gernas Kakao. Program tersebut diluncurkan pada tahun 2009 dengan melaksanakan peremajaan pada perkebunan kakao yang terletak di seluruh Indonesia. Program Gernas Kakao resmi diberhentikan pada pergantian pemerintah tahun 2014. Pada sektor hilir, pemerintah melalui Kementerian Keuangan menerapkan peraturan nomor 67/PMK.011/2010 yang mengatur tentang tarif ekspor untuk biji kakao guna menurunkan penawaran ekspor biji kakao oleh produsen dalam negeri dan meningkatkan ekspor produk olahan kakao. Kebijakan tersebut terbukti efektif dalam meningkatkan ekspor produk olahan kakao dimana setelah tahun 2010, ekspor produk olahan kakao terutama bubuk kakao dan lemak kakao mengalami peningkatan. Sementara itu, ekspor biji kakao terus mengalami penurunan. Pada periode tahun 2010-2018, Indonesia meningkatkan volume impor biji kakao yang bertujuan untuk memenuhi kebutuhan industri terhadap biji kakao, menginat produksi dalam negeri yang terus menurun. Peningkatan impor biji kakao yang signifikan mengindikasikan adanya peningkatan pada permintaan industri hilir terhadap biji kakao.

Peraturan dan kebijakan-kebijakan yang dibuat oleh pemerintah yang bertujuan untuk mengembangkan industri hilir kakao diharapkan dapat meningkatkan volume produksi produk hilir kakao oleh produsen-produsen yang berada di Indonesia. Peluncuran program Gernas Kakao oleh pemerintah untuk meningkatkan jumlah dan kualitas produksi biji kakao serta peningkatan impor biji kakao dalam beberapa tahun terakhir juga diharapakan dapat meningkatkan penyerapan biji kakao oleh industri hilir domestik. Kebijakan pemerintah pada sektor hilir kakao terbukti telah mempengaruhi perkembangan industri hilir kakao di Indonesia dengan berkurangnya ekspor biji kakao dan meningkatnya ekspor olahan kakao terutama berupa lemak kakao dan bubuk kakao. Berdasarkan uraian tersebut, perlu dilakukan analisis mengenai trend perubahan konsumsi biji kakao oleh industri hilir, produksi biji kakao, volume ekspor biji kakao, dan produksi produk hilir kakao. Serta perlu dilakukan penelitian mengenai permintaan industri hilir domestik terhadap biji kakao dan faktor-faktor yang mempengaruhinya. 


\section{Metode Penelitian}

Penelitian ini menggunakan desain penelitian kuantitatif. Penelitian kuantitatif adalah penelitian yang digunakan untuk mengamati suatu populasi atau sampel tertentu dengan mengumpulkan data melalui instrumen penelitian yang telah dipilih lalu menganalisis data tersebut menggunakan statistika untuk menguji hipotesis yang sudah ditetapkan (Sugiyono, 2017). Penelitian kuantitatif dilakukan dengan pendekatan ekonometrik. Data pada penelitian ini merupakan data sekunder berupa time-series dari tahun 2002-2017. Data dikumpulkan dengan teknik tinjauan dokumen.

analisis deskriptif digunakan dalam penelitian ini untuk mendeskripsikan trend perubahan konsumsi industri hilir terhadap biji kakao, produksi biji kakao, produksi produk hilir, dan volume ekspor biji kakao. Trend perubahan dideskripsikan menggunakan tabel dan grafik yang menunjukkan garis trend. Faktor-faktor yang mempengaruhi permintaan industri hilir terhadap biji kakao akan diidentifikasi dengan menggunakan analisis regresi linier berganda dengan metode estimasi Ordinary Least Squares (OLS). Spesifikasi model regresi yang digunakan dalam penelitian ini adalah sebagai berikut :

$$
\text { DBK }=a_{0}+a_{1} \text { HBKD }+a_{2} \text { HLKD }+a_{3} \text { HBUKD }+a_{4} \text { PLKD }+a_{5} \text { PBUKD }+\mu
$$

Keterangan :

$\begin{array}{ll}\text { DBK } & =\text { Permintaan biji kakao } \\ \text { HBKD } & =\text { Harga riil biji kakao domestik } \\ \text { HLKD } & =\text { Harga riil lemak kakao domestik } \\ \text { HBUKD } & =\text { Harga riil bubuk kakao domestik } \\ \text { PLKD } & =\text { Produksi lemak kakao domestik } \\ \text { PBUKD } & =\text { Produksi bubuk kakao domestik } \\ a_{0} & =\text { Konstanta regresi } \\ a_{1}, a_{2}, a_{3} & =\text { Koefisien regresi variabel bebas } \\ \mu & =\text { Variabel yang tidak diperhitungkan }\end{array}$

\section{Hasil dan Pembahasan}

\section{1) Trend Perubahan Konsumsi, Produksi, dan Ekspor Kakao Indonesia}

\section{Trend Perubahan Produksi Biji Kakao Domestik}

Gambar 1 menunjukkan perubahan produksi biji kakao dari tahun 2002 hingga tahun 2017. Produksi biji kakao domestik pada tahun 2002-2010 terus mengalami peningkatan. Produksi biji kakao oleh Indonesia mencapai 837.918 ton pada tahun 2010. Namun, setelah tahun 2010 produksi biji kakao Indonesia terus mengalami penurunan hingga tahun 2017 dimana produksi biji kakao Indonesia sebesar 590.684 ton. 


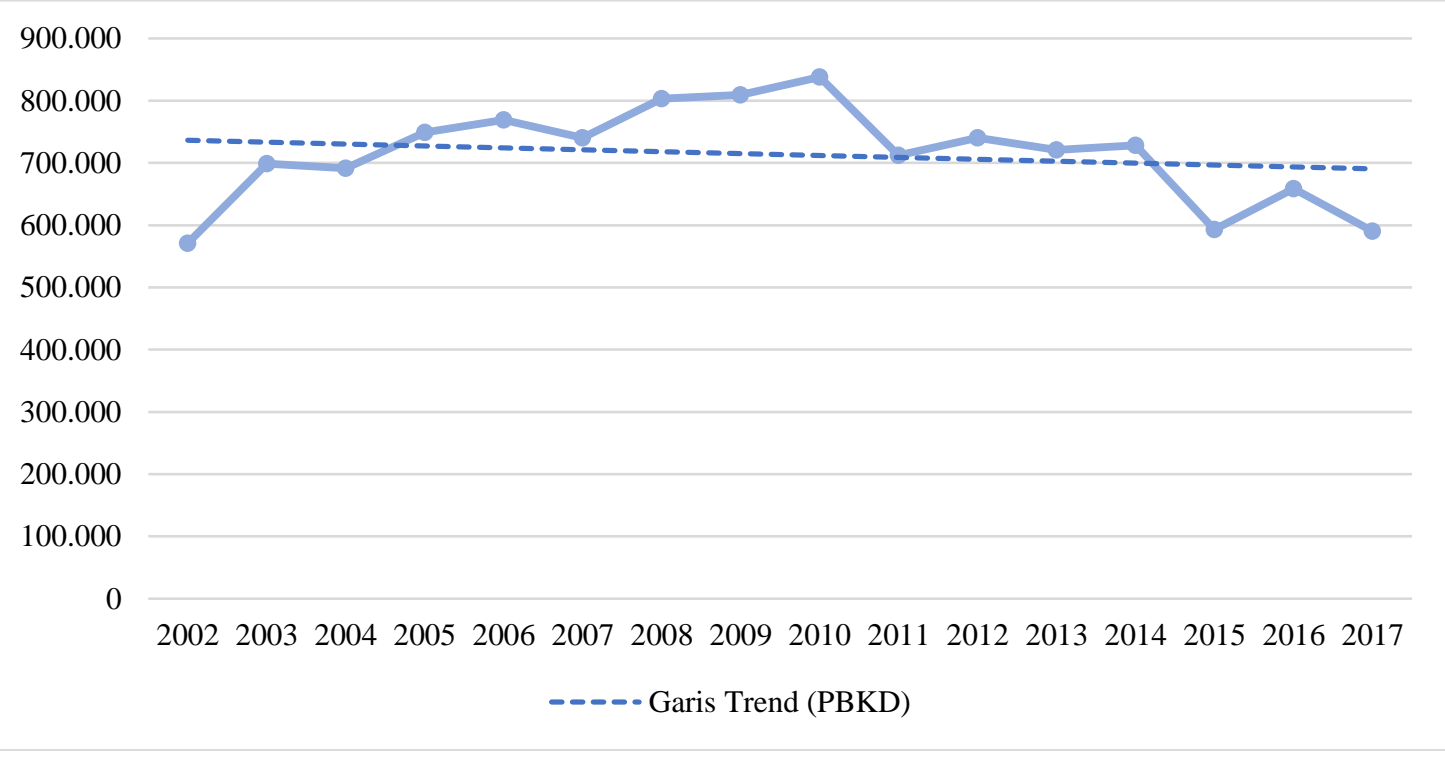

Gambar 1

Trend Perubahan Produksi Biji Kakao Domestik Tahun 2002-2017

Secara garis besar, garis trend menunjukkan bahwa dari tahun 2012-2017 produksi biji kakao terus mengalami penurunan. Penelitian yang dilakukan Jasman (2016) menyatakan bahwa penyebab produksi biji kakao Indonesia terus mengalami penurunan adalah umur tanaman kakao yang sudah tidak produktif lagi, yaitu diatas 25 tahun. Hal ini juga dikuatkan oleh penelitian yang dilakukan Komite Pemantaun Pelaksanaan Otonomi Daerah (2013) di Kabupaten Majene, Sulawesi Barat dan Rinaldi dkk (2013) di Provinsi Bali yang menyatakan bahwa penurunan produksi kakao di masing-masing daerah tersebut disebabkan oleh umur tanaman yang sudah tidak produktif, serta serangan hama dan penyakit yang tidak diantisipasi dengan baik. Menurut penelitian yang dilakukan oleh Center for Indonesian Policy Studies (2019), penyebab lain penurunan produksi biji kakao Indonesia adalah bahwa perkebunan kakao di Indonesia didominasi oleh perkebunan dengan kepemilikan rakyat yang memiliki modal relatif lebih rendah dibandingkan perkebunan negara maupun swasta. Hal ini menyebabkan petani penghasil kakao tidak memiliki kemampuan maupun keberanian untuk mengambil risiko yaitu membeli bibit tanaman kakao yang baru menghasilkan buah kakao setelah lima tahun. Pada akhirnya, petani-petani penghasil kakao tersebut meninggalkan komoditas kakao untuk memproduksi komoditas lain yang lebih rendah risiko.

\section{Trend Perubahan Konsumsi Biji Kakao Oleh Industri Hilir Domestik}

Pada Gambar 2, ditunjukkan bahwa terjadi peningkatan pada konsumsi biji kakao oleh industri bubuk kakao dan lemak kakao domestik pada tahun 2003 dari tahun sebelumnya. Setelah tahun 2003, perubahan konsumsi biji kakao bersifat fluktuatif yaitu mengalami penurunan maupun peningkatan hingga tahun 2009. Konsumsi biji kakao setelah tahun 2009 terus mengalami peningkatan dan mencapai puncak pada periode tersebut di tahun 2017 dengan konsumsi biji kakao sebesar 792.200 ton. Garis trend pada Gambar 8 menunjukkan bahwa secara garis besar, konsumsi biji kakao oleh industri hilir terus mengalami peningkatan. Peningkatan konsumsi biji kakao oleh industri hilir disebabkan oleh perkembangan pada industri hilir kakao domestik terutama setelah tahun 2009. 


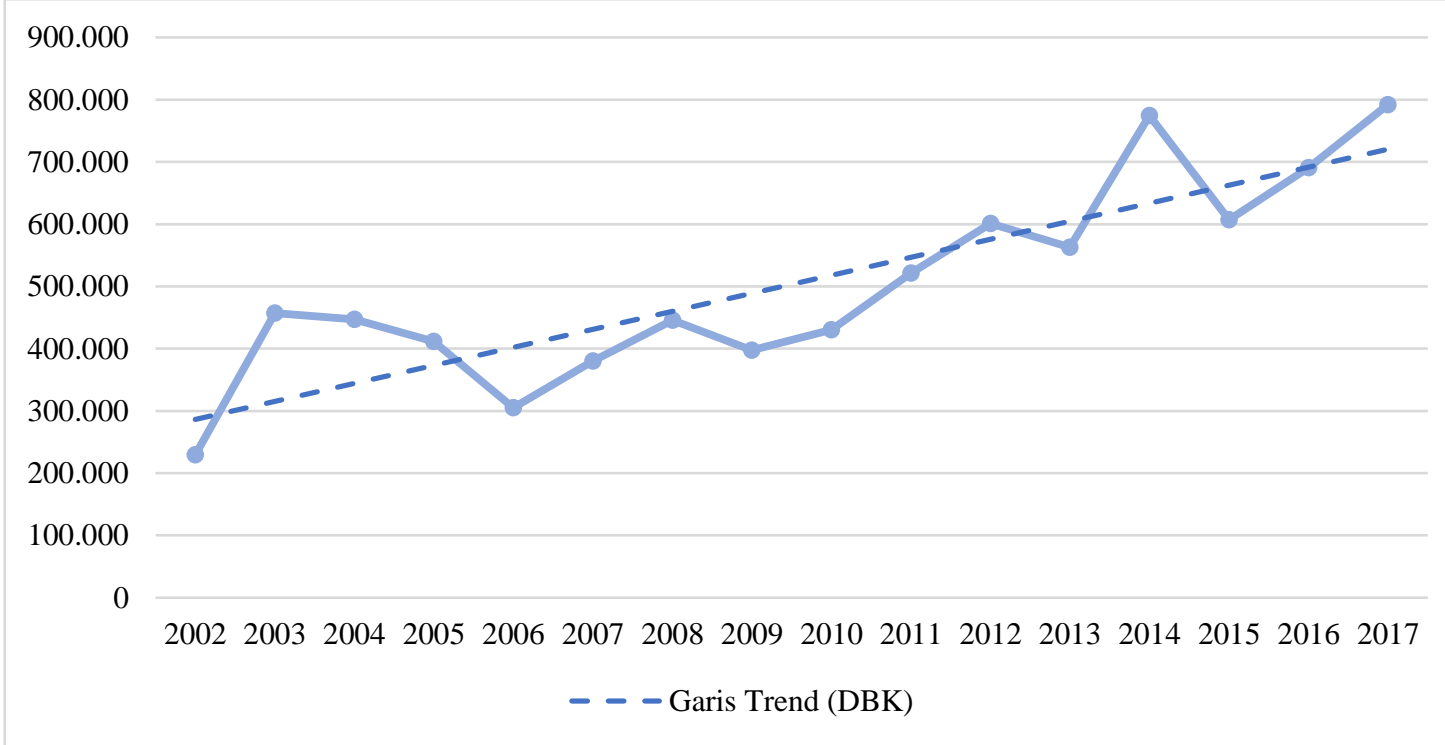

Gambar 2

Trend Perubahan Konsumsi Biji Kakao Oleh Industri Hilir Domestik

Laporan yang dihasilkan oleh Badan Koordinasi Penanaman Modal kepada Kementerian Perdagangan (2014) menunjukkan bahwa pada tahun 2009 hingga 2014 terdapat dana yang ditanamkan oleh investor asing pada industri pengolahan kakao sebesar US\$ 437,53 juta yang berasal Singapura, Belgia, British Virgin Islands, Malaysia, Amerika Serikat, dan negaranegara lainnya dimana $80 \%$ dana tersebut terkonsentrasi di Pulau Jawa dan sisanya tersebar di Pulau Sulawesi dan Sumatera. Sedangkan investor lokal menanamkan modal sebesar 5,68 triliun rupiah yang utamanya berada di Provinsi Banten sebesar 98,5\% dan 1,5\% berada di Jawa Barat dan Jawa Timur.

Struktur konsumsi biji kakao oleh industri hilir domestik masih didominasi oleh biji kakao produksi dalam negeri. Namun, dalam beberapa tahun ke depan struktur konsumsi biji kakao dapat berubah. Hal ini disebabkan oleh trend penurunan produksi biji kakao domestik yang ditunjukkan pada Tabel 7. Sementara itu, perkembangan impor biji kakao oleh Indonesia ditunjukkan pada Gambar 3, dimana setelah tahun 2014 khususnya menuju tahun 2017, terjadi lonjakan pada volume impor biji kakao yang sangat signifikan dari tahun-tahun sebelumnya. Faktor kualitas juga menjadi alasan industri pengolahan kakao domestik memilih biji kakao impor. Mayoritas dari perkebunan rakyat yang memproduksi biji kakao tidak melakukan fermentasi terhadap biji yang sudah dipanen (Center for Indonesian Policy Studies, 2019). Hal ini menyulitkan pengolah biji kakao karena biji kakao yang tidak difermentasi tidak menghasilkan cita rasa yang baik (Askindo, 2005). Selain itu, biji kakao hasil produksi Indonesia memiliki kadar logam berat berupa kadmium yang lebih tinggi dibandingkan biji kakao asal Pantai Gading dan Ghana (Jasman, 2016).

\section{Trend Perubahan Produksi Produki Hilir Kakao Domestik}

Produk hilir kakao dalam penelitian ini dibatasi pada produk setengah jadi industri kakao yang tingkat produksi dan ekspor paling tinggi dibanding produk kakao setengah jadi lainnya yaitu bubuk kakao dan lemak kakao. Gambar 3 menunjukkan bahwa perubahan produksi produk hilir kakao pada periode tahun 2002 hingga 2017 secara garis besar mengalami peningkatan disertai fluktuasi pada tahun 2011 menuju tahun 2017. Hingga tahun 2011 produksi bubuk kakao dan lemak kakao terus mengalami peningkatan. 


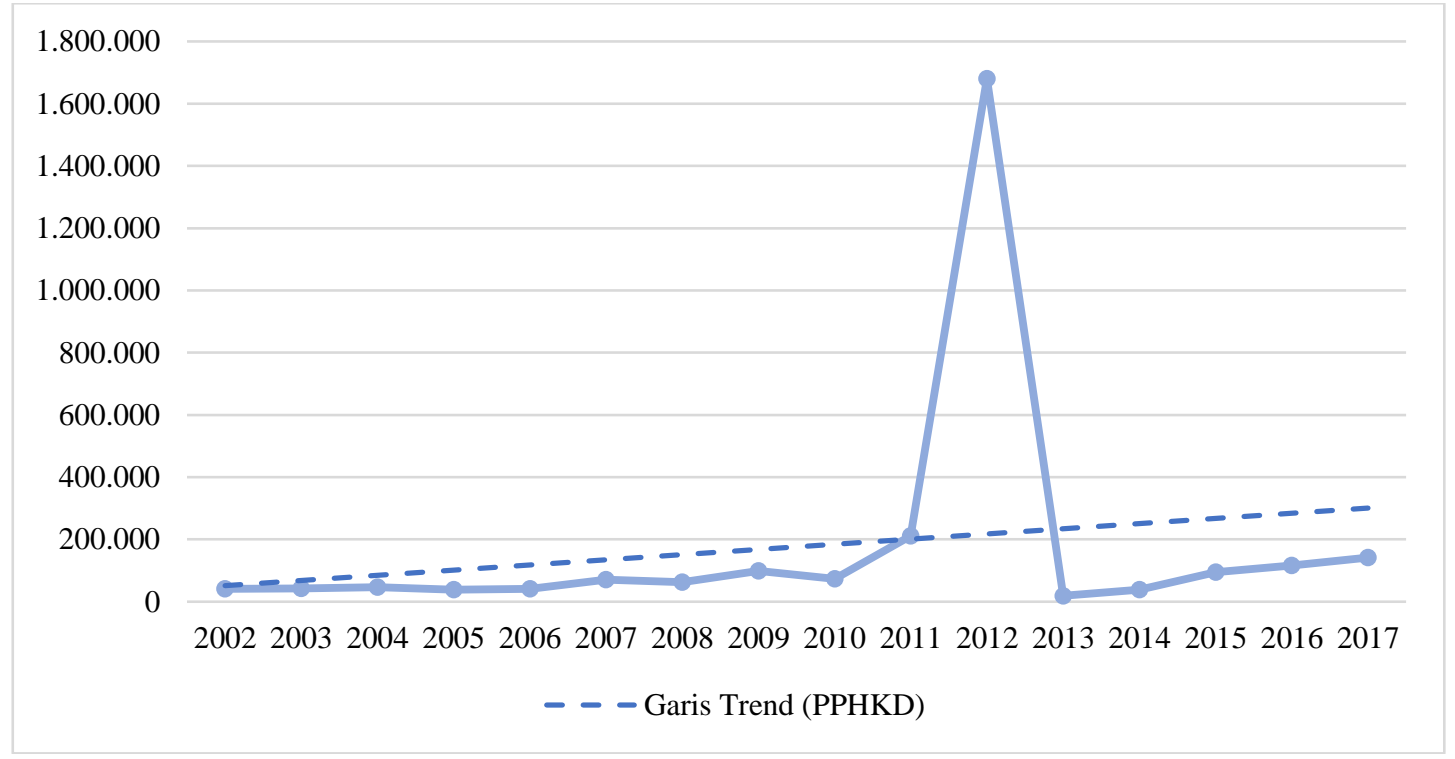

Gambar 3

Trend Perubahan Produksi Produk Hilir Tahun 2002-2017

Menurut Direktorat Jenderal Industri Agro Kementerian Perindustrian (2014), setelah tahun 2010 terjadi penambahan jumlah pabrik pengolahan lokal. Pada tahun 2010 pabrik pengolahan kakao lokal berjumlah tujuh unit dan pada tahun 2013 telah terjadi penambahan sebanyak sebelas unit pabrik pengolahan kakao menjadi 14 unit. Penambahan jumlah pabrik juga diikuti oleh peningkatan pada persentase utilitas produksi. Persentase utilitas produksi adalah perbandingan kapasitas terpakai terhadap kapasitas yang terpasang. Persentase utilitas produksi pada tahun 2011 adalah sebesar 46,21\%, dan hingga tahun 2014 terus meningkat mencapai $63,29 \%$.

\section{Trend Perubahan Volume Ekspor Biji Kakao}

Trend perubahan volume ekspor biji kakao ditunjukkan pada Gambar 10. Volume ekspor biji kakao pada periode tahun 2002-2017 mengalami trend penurunan. Penurunan yang signifikan terjadi setelah tahun 2010, dimana sebelum tahun 2010 perkembangan volume ekspor biji kakao bersifat fluktuatif. Volume ekspor biji kakao pada tahun 2011 adalah 210.066 ton, menurun 105\% dari tahun 2010 dimana volume ekspor biji kakao adalah sebesar 432.426 ton dan terus menerus mengalami penurunan hingga mencapai titik terendah pada tahun 2017 yaitu sebesar 25.097 ton. 


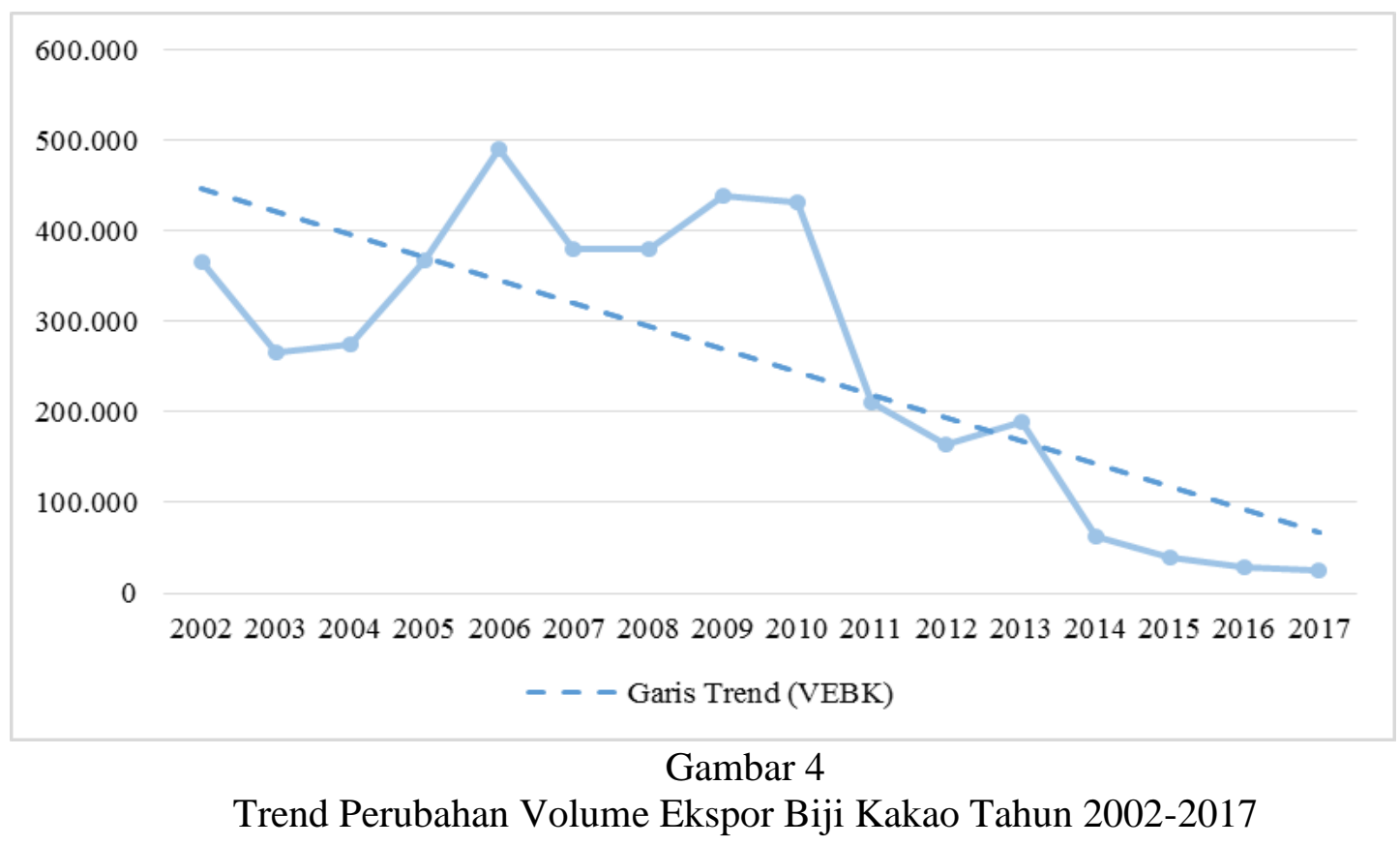

Penurunan pada volume ekspor biji kakao utamanya disebabkan oleh penerapan tarif bea keluar biji kakao yang ditetapkan oleh Kementerian Perdagangan. Hal ini dilakukan sebagai salah satu bentuk realisasi pembangunan industri hasil hutan dan perkebunan yang tertera pada Rencana Pembangunan Jangka Menengah Nasional (RPJMN) tahun 2019-2014. Menurut Bonarriva (2009), penerapan bea keluar dapat bermanfaat bagi kepentingan suatu negara, yaitu untuk menjaga stabilitas ketersediaan maupun harga domestik, serta mendorong pembangunan industri domestik yang dapat menyebabkan multiplier effect pada aspek-aspek lainnya.

\section{2) Faktor-Faktor yang Mempengaruhi Permintaan Industri Hilir Domestik Terhadap Biji Kakao}

Faktor-faktor yang mempengaruhi permintaan industri hilir domestik terhadap biji kakao diidentifikasi menggunakan analisis regresi linier berganda. Model regresi linier berganda dengan menggunakan metode OLS harus memenuhi asumsi dan syarat BLUE yaitu best linear unbiased estimate dan dikenal sebagai teori Gauss-Markov (Baltagi, 2011). Pemenuhan syarat BLUE sebuah model regresi dapat dilakukan dengan melakukan beberapa pengujian yaitu uji asumsi klasik, uji hipotesis, dan uji kelayakan model regresi (Kutner et al. 2004). Uji asumsi klasik terdiri dari uji normalitas yang digunakan untuk mengetahui apakah data dalam model regresi berdistrubusi normal, uji autokorelasi untuk mengetahui apakah pada data periode ke-n dengan periode sebelumnya terdapat korelasi, uji multikolonieritas untuk mengetahui apakah terdapat korelasi antara variabel bebas dan variabel terikat, serta uji heteroskedastisitas untuk mengetahui apakah terjadi ketidaksamaan varian dari residual pengamatan ke pengamatan lain dalam model regresi (Ghozali, 2011). Uji hipotesis terdiri dari uji F yaitu uji parameter secara simultan dan uji $\mathrm{T}$ yaitu uji parameter secara parsial. Uji kelayakan model regresi dilakukan untuk mengetahui tingkat kemampuan variabel bebas dalam menjelaskan variabel terikat pada model. 
Tabel 1

ANOVA

\begin{tabular}{|c|c|c|}
\hline Model & $\mathrm{F}$ & Sig. \\
\hline Regression & \multirow[t]{3}{*}{8,286} & \multirow[t]{3}{*}{, $003^{b}$} \\
\hline Residual & & \\
\hline Total & & \\
\hline
\end{tabular}

Sumber : Pengolahan data sekunder (2020)

Berdasarkan nilai signifikansi pada hasil uji F yang ditunjukkan pada Tabel 1, dapat dikatakan bahwa variabel-variabel bebas pada model secara simultan berpengaruh signifikan terhadap variabel terikat. Nilai signifikansi $0,003<0,1$ yang berarti bahwa hipotesis $\mathrm{H}_{0}$ ditolak dan $\mathrm{H}_{1}$ diterima.

Tabel 2

Coefficient

\begin{tabular}{|c|c|c|c|}
\hline \multirow[b]{2}{*}{ Model } & \multicolumn{2}{|c|}{ Unstandardized Coefficients } & \multirow[b]{2}{*}{ Sig. } \\
\hline & $\mathrm{B}$ & Std. Error & \\
\hline \multirow{2}{*}{ (Constant) } & 104497.202 & 121090.142 & .408 \\
\hline & -.679 & 1.172 & $* * .014$ \\
\hline HBKD & 3.500 & 2.215 & $* .056$ \\
\hline HLKD & .652 & 1.242 & $* .071$ \\
\hline \multirow{2}{*}{ HBUKD } & 1.597 & 1.576 & .335 \\
\hline & .126 & .061 & $* .065$ \\
\hline
\end{tabular}

Sumber : Pengolahan data sekunder (2020)

Tabel 2 menunjukkan hasil uji T. Model regresi dapat disusun menggunakan nilai unstandardized coefficient. Berdasarkan nilai unstandardized coefficient yang diperoleh dari uji T (Tabel 2), model regresi adalah sebagai berikut :

$$
\mathrm{DBK}=-0,679 \mathrm{HBKD}+3,500 \mathrm{HLKD}+0,652 \mathrm{HBUKD}+1,597 \mathrm{PLKD}+0,126 \mathrm{PBUKD}
$$

Keterangan:

$\begin{array}{ll}\text { DBK } & =\text { Permintaan biji kakao } \\ \text { HBKD } & =\text { Harga riil biji kakao domestik } \\ \text { HLKD } & =\text { Harga riil lemak kakao domestik } \\ \text { HBUKD } & =\text { Harga riil bubuk kakao domestik } \\ \text { HLKD } & =\text { Produksi lemak kakao domestik } \\ \text { PBUKD } & =\text { Produksi bubuk kakao domestic } \\ \mathrm{a}_{0} & =\text { Konstanta regresi } \\ \mathrm{a}_{1}, \mathrm{a}_{2}, \mathrm{a}_{3} & =\text { Koefisien regresi variabel bebas } \\ \mu & =\text { Variabel yang tidak diperhitungkan }\end{array}$

Berdasarkan nilai signifikansi dan unstandardized coefficient yang diperoleh dari hasil uji t, pengaruh variabel harga riil biji kakao domestik (HBKD), harga riil lemak kakao doemstik 
(HLKD), harga riil bubuk kakao domestik (HBUKD), produksi lemak kakao domestik (HLKD), dan produksi bubuk kakao domestik (PBUKD) dapat dijelaskan sebagai berikut :

\section{a. Harga Riil Biji Kakao}

Hasil uji parameter secara parsial menunjukkan bahwa variabel HBKD memiliki nilai signifikansi 0,014. Hal ini menunjukkan bahwa harga riil biji kakao domestik berpengaruh signifikan terhadap permintaan biji kakao oleh industri hilir kakao domestik pada taraf nyata (a) 0,05 atau 5\%. Hasil tersebut sesuai dengan hipotesis penelitian. Berdasakan hasil regresi linier berganda, nilai koefisien variabel HBKD adalah -,679 yang menunjukkan bahwa, variabel harga riil biji kakao domestik memiliki pengaruh negatif terhadap permintaan industri hilir domestik terhadap biji kakao, dimana peningkatan sebesar Rp100.000/ton pada harga riil biji kakao domestik akan menurunkan permintaan biji kakao oleh industri hilir sebesar 67,9 ton dan berlaku sebaliknya dengan anggapan faktor-faktor lain dalam keadaan konstan (ceteris paribus)

\section{b. Harga Riil Lemak Kakao}

Variabel harga riil lemak kakao domestik (HLKD) memiliki nilai signifikansi 0,056 yang berarti bahwa harga riil lemak kakao domestik berpengaruh signifikan terhadap permintaan industri hilir domestik terhadap biji kakao pada taraf nyata $(\alpha) 0,1$ atau $10 \%$. Hasil tersebut sesuai dengan hipotesis penelitian. Nilai koefisien variabel HLKD berdasarkan hasil analisis regresi linier berganda adalah 3,500 yang berarti bahwa harga riil lemak kakao domestik mempengaruhi permintaan industri hilir domestik terhadap biji kakao secara positif. Hal ini memiliki arti bahwa peningkatan sebesar Rp100.000/ton pada harga riil biji kakao domestik menyebabkan peningkatan pada permintaan industri hilir domestik terhadap biji kakao sebesar 350 ton dengan asumsi bahwa faktor-faktor lain dianggap tetap (ceteris paribus).

\section{c. Harga Riil Bubuk Kakao}

Hasil uji parameter secara parsial menunjukkan variabel harga bubuk kakao memiliki nilai signifikansi sebesar 0,071 yang berarti bahwa pada taraf nyata $(\alpha) 0,10$ atau $10 \%$, harga riil bubuk kakao domestik berpengaruh signfikan terhadap permintaan industri hilir domestik terhadap biji kakao. Hal ini sesuai dengan hipotesis penelitian. Nilai koefisian variabel HBUKD yang diperoleh dari hasil analisis regresi linier berganda adalah 0,652 yang berarti bahwa harga riil bubuk kakao domestik mempengaruhi permintaan biji kakao oleh industri hilir secara positif. Hal tersebut memiliki pengertian bahwa, peningkatan sebesar Rp100.000/ton pada harga riil bubuk kakao domestik menyebabkan peningkatan sebesar 65 ton apabila diasumsikan faktor-faktor lain dalam keadaan konstan (ceteris paribus).

\section{d. Produksi Lemak Kakao Domestik}

Variabel produksi lemak kakao domestik (PLKD) berdasarkan uji parameter parsial memiliki nilai signfikansi 0,335 yang berarti bahwa produksi lemak kakao domestik tidak berpengaruh signifikan terhadap permintaan industri hilir domestik terhadap biji kakao. Hal tersebut tidak sesuai dengan hipotesis penelitian. Variabel PLKD memiliki nilai koefisien sebesar 1,597. Hal ini memiliki pengertian bahwa peningkatan pada produksi lemak kakao domestik sebesar 100 ton akan menyebabkan peningkatan sebesar 159,7 ton pada permintaan industri hilir domestik terhadap biji kakao

\section{e. Produksi Bubuk Kakao Domestik}

Analisis regresi linier berganda menunjukkan bahwa nilai signifikansi dari variabel produksi bubuk kakao domestik (PBUKD) adalah 0,065 yang memiliki arti bahwa produksi bubuk kakao domestik berpengaruh signifikan terhadap permintaan industri hilir domestik terhadap biji kakao pada taraf nyata $(\alpha) 0,10$ atau $10 \%$. Hal tersebut sesuai dengan hipotesis penelitian. 
Variabel produksi bubuk kakao domestik memiliki nilai koefisien sebesar 0,126 yang memiliki pengertian bahwa produksi bubuk kakao domestik mempengaruhi permintaan biji kakao oleh industri hilir secara positif. Peningkatan sebesar 100 ton pada produksi bubuk kakao domestik akan meningkatkan permintaan industri hilir domestik terhadap biji kakao sebesar 12,6 ton.

Tabel 3. Model Summary

\begin{tabular}{llll} 
Model & $\mathrm{R}$ & & R Square \\
1 & & $.898^{\mathrm{a}}$ & \\
\hline
\end{tabular}

a. Predictors: (Constant), HBKD, HBUKD, HLKD, PBUKD, PLKD

Tabel 3 menunjukkan hasil uji kelayakan model regresi. Uji kelayakan model regresi dilakukan dengan cara menganalisis nilai koefisien determinasi $\left(\mathrm{R}^{2}\right)$. Pada Tabel 3 ditunjukkan bahwa nilai koefisien determinasi atau $\mathrm{R}^{2}$ adalah 0,806 atau setara dengan $80,6 \%$ yang memiliki pengertian bahwa variabel-variabel bebas yang digunakan dalam model pada penelitian ini dapat menjelaskan variabel terikatnya dengan baik. Variabel harga riil biji kakao variabel, variabel harga riil bubuk kakao, variabel harga riil lemak kakao, variabel produksi bubuk kakao, dan variabel produksi lemak kakao dapat menjelaskan permintaan industri hilir domestik terhadap biji kakao sebesar 80,6\% sedangkan 19,4\% lainnya dijelaskan oleh variabel yang tidak digunakan dalam penelitian ini.

\section{Kesimpulan}

Produksi produk hilir kakao dan konsumsi biji kakao oleh industri hilir pada periode tahun 2002-2017 mengalami trend peningkatan yang disebabkan oleh kebijakan-kebijakan pemerintah. Sementara itu, produksi biji kakao dan volume ekspor bij kakao pada periode yang sama mengalami trend penurunan.

Faktor-faktor yang mempengaruhi permintaan industri hilir kakao domestik terhadap biji kakao secara signifikan adalah harga riil biji kakao domestik, harga riil lemak kakao domestik, harga riil bubuk kakao domestik, dan produksi bubuk kakao domestik. Produksi lemak kakao domestik tidak berpengaruh signifikan terhadap permintaan biji kakao oleh industri hilir. Hal ini disebabkan oleh produksi lemak kakao yang lebih rendah dibandingkan produksi bubuk kakao sehingga perubahan pada produksi lemak kakao tidak menyebabkan perubahan signifikan pada permintaan industri hilir domestik terhadap biji kakao.

\section{Ucapan Terimakasih}

Penulis mengucapkan terima kasih kepada seluruh pihak yang telah membantu dalam menyelesaikan penelitian ini.

\section{Daftar Pustaka}

Badan Pusat Statistik. 2020. Distribusi Pdb Triwulanan Atas Dasar Harga Berlaku Menurut Lapangan Kerja Tahun 2016-2019. Badan Pusat Statistik

Badan Pusat Statistik. 2019. Statistik Perkebunan Kakao 2018. Badan Pusat Statistik.

Badan Pusat Statistik. 2019. Statistik Industri Manufaktur 2017: Produksi. Badan Pusat Statistik.

Baltagi, B.H. 2011. Econometrics Fifth Edition. Springer Books. 
Bonarriva, J., Koscielski, M., \& Wilson, E. (2009). Export Control: An Overview of Their Use, Economic Effect, and Treatment in the Global Trading System. Office of Industries Working Paper U.S International Trade Commission , 23.

Center for Indonesian Policy Studies. 2019. Private Sector Initiatives To Boost Productivity of Cocoa, Coffee, and Rubber in Indonesia. Center for Indonesian Policy Studies: Jakarta.

Direktorat Jenderal Perkebunan. 2018. Statistik Perkebunan Indonesia 2017-2019: Kakao. Direktorat Jenderal Perkebunan Indonesia.

Food and Agriculture Organization of The United Nations. 2010-2018. FAOSTAT Database Produksi Kakao Dunia Tahun 2010-2018.http://fao.org/faostat/en. Diakses pada tanggal 15 Mei 2020

Ghozali, Imam. 2011. Aplikasi Analisis Multivariate Dengan Program SPSS. Semarang: Badan Penerbit Universitas Diponegoro.

Henderson, J.M, dan Richard Quandt. 1980. Microeconomic Theory: A Mathematical Approach. New York: McGraw-Hill Book Company, Inc.

Jasman, Thomas. (2016). Indonesia's cocoa industry: Lack of supply still hampers growth and investment. Global Business Indonesia Guide.

Kementerian Perdagangan. 2014. Laporan Akhir Pembebasan Bea Masuk Biji Kakao. Kementerian Perdagangan: Jakarta.

Kementerian Perindustrian Indonesia. 2007. Gambaran Sekilas Industri Kakao. Kementerian Perindustrian Indonesia.

Kementerian Pertanian Indonesia. 2016. Outlook Kakao 2016. Jakarta. Kementerian Pertanian Indonesia.

Komite Pemantauan Pelaksanaan Otonomi Daerah. 2013. Kebutuhan Pengembangan Usaha Kakao dengan Pendekatan Rantai Nilai dan Evaluasi Gerakan Nasional Peningkatan dan Mutu Kakao. KPPOD: Jakarta.

Kutner, M.H., Nachtsheim, C.J., Neter, J., Li, W. 2004. Applied linear Statistic Model Fifth Edition. New York: McGraw-Hill Book Company, Inc.

Mankiw, N.G. 2018. Principles of Microeceonomics. Boston: Cengage Learning

Peraturan Menteri Keuangan Nomor 67/PMK.011/2010 tentang Penetapan Barang Ekspor yang Dikenakan Tarif Bea Ekspor.

Peraturan Menteri Pertanian Nomor 67/Permentan/OT.140/5/2014 tentang Persyaratan Mutu dan Pemasaran Biji Kakao.

Pratiwi, C.I. 2014. Analisis Permintaan Minyak Sawit Indonesia oleh Industri Minyak Goreng, Margarin, Sabun, dan Fatty Acid. [Skripsi]. Bogor: Institut Pertanian Bogor

Pyndick, R., Rubinfeld, D. 2018. Microeconomics: 9th Edition. Pearson Education

Rifin, A. 2013. Competitiveness of Indonesia's Cocoa Beans Export in The World Market. International Journal of Trade, Economics and Finance 4(5). 
Senteri, Z. 1988. An Econometric Analysis of The United States' Palm Oil Market. Jurnal Ekonomi Malaysia

Siregar, T.H.S, Riyadi, S., Nuraeni, L. 2011. Budi Daya Cokelat. Depok: Penebar Swadaya.

Soeharno, T.S. 2006. Teori Mikroekonomi. Yogyakarta: Penerbit Andi.

Sugiyono. 2017. Metode Penelitian Kuantitatif. Bandung : Alfabeta.

Sukirno, Sadono. 2011. Mikroekonomi: Teori Pengantar Edisi Ketiga. Jakarta: Rajawali Pers.

[UN Comtrade] The United Nations Commodity Trade. 1989-2018. Database Ekspor Biji Kakao, Lemak Kakao, Bubuk Kakao, dan Pasta Kakao Tahun 2014-2018. http://comtrade.un.org/data. Diakses pada tanggal 16 Mei 2020. 